У ДК 691.3; 691.5

РЕГУЛЮВАННЯ ВЛАСНИХ ДЕФОРМАЦЙ ШЛАКОЛУЖНИХ ДРІБНОЗЕРНИСТИХ БЕТОНІВ КОМПЛЕКСНИМИ БАГАТОФУНКЦІОНАЛЬНИМИ ДОБАВКАМИ ДЛЯ ПОПЕРЕДЖЕННЯ КОРОЗЇ̈ СТАЛЕВОЇ АРМАТУРИ

Д-р техн. наук П. В. Кривенко, кандидати техн. наук О. М. Петропавловський, І. І. Руденко, О. П. Констатиновський

\title{
CONTROL OF ALKALI-ACTIVATED SLAG CEMENT FINE CONCRETES PROPER DEFORMATIONS BY COMPLEX MULTIFUNCTIONAL ADDITIVES BASED ON SALTS-ELECTOLYTES FOR PREVENTION OF STEEL REINFORCEMENT CORROSION
}

D. Sc. (Tech.) P. V. Krivenko, PhD (Tech.) O. M. Petropavlovskyi, PhD (Tech.) I. I. Rudenko, PhD (Tech.) O. P. Konstantynovskyi

DOI: https://doi.org/10.18664/1994-7852.189.2020.213163

Анотація. Запропоновано комплексні багатофункиіональні добавки на основі солейелектролітів $\mathrm{NaNO}_{3}, \mathrm{Na}_{2} \mathrm{SO}_{4}$ i $\mathrm{Na}_{3} \mathrm{PO}_{4}$, що забезпечують зменшення усадки дрібнозернистого бетону на основі шлаколужного иементу з 0,984 до 0,560-0,605 мм/м, 0,625-0,640 мм/м $i$ 0,713-0,700 мм/м відповідно. Зменшення деформацій усадки дрібнозернистих бетонів розглядається як засіб запобігання корозії сталевої арматури.

Ключові слова: илаколужний иемент, дрібнозернистий бетон, сіль-електроліт, поверхнево-активна речовина, комплексна добавка, корозія сталевої арматури, усадка, міиність.

Abstract. The actuality of alkali-activated slag cements (AASC) implementation is due to their conformity with modern tendencies concerning efficient consumption of raw materials and energy, while ensuring high functionality of mortars and concretes. AASC concretes are characterized by increased strength, sulfate resistance, freeze-thaw resistance and weather resistance in comparison with analogues based on traditional clinker cements. The modern requirements to high consistency fresh concretes are governed by practice. This way the disturbance of reinforcement passive state can be caused by changes in hardened concrete structure. Shrinkage reduction of AASC concretes 
due to complex multifunctional additives (CA's) based on salts-electrolytes is seen as a way to prevent corrosion of steel reinforcement. The aim of the paper is substantiation of CA's presented by the system «ordinary portland cement clinker (OPC clinker) - salt-electrolyte - surfactant» for adjustment of proper deformations and strength of AASC fine concrete with increasing density to prevent corrosion of steel reinforcement.

Modification of AASC by $\mathrm{CA}$ based on $\mathrm{NaNO}_{3}$ provides shrinkage reduction from 0,984 down to 0,560 - 0,605 mm/m $\left(t=20 \pm 2{ }^{\circ} \mathrm{C}, \mathrm{R} . \mathrm{H} .=65 \%\right)$. Unlike, CA based on $\mathrm{Na}_{2} \mathrm{SO}_{4}$ causes shrinkage mitigation down to 0,625-0,640 mm/m. CA based on $\mathrm{Na}_{3} \mathrm{PO}_{4}$ minimizes shrinkage to 0,713 - 0,700 $\mathrm{mm} / \mathrm{m}$. Shrinkage mitigation is explained by less water, higher crystallinity of hydrated phases as well as by formation of minamiit $\left(\mathrm{Na}, \mathrm{Ca}_{0.5}\right) \mathrm{Al}_{3}\left(\mathrm{SO}_{4}\right)_{2}(\mathrm{OH})_{6}$, calcium hydronitroaluminate $3 \mathrm{CaO} \cdot \mathrm{Al}_{2} \mathrm{O}_{3} \cdot \mathrm{Ca}\left(\mathrm{NO}_{3}\right)_{2} \cdot 1 \mathrm{OH}_{2} \mathrm{O}$ and calcium hydroxylapatite $\mathrm{Ca} 10\left(\mathrm{PO}_{4}\right)_{6}(\mathrm{OH})_{2}$ crystals versus saltelectrolyte as ingredient of CA's. The 28 day compressive strength of modified AASC concrete is not less than the reference one.

Keywords: alkali-activated slag cement, fine concrete, salt-electrolyte, surfactant, complex additive, steel reinforcement corrosion, shrinkage, strength.

Вступ. Сучасні тенденції у світовому матеріалознавстві актуалізують питання запровадження цементів, альтернативних традиційним, виробництво яких здійснюється за ресурсо- та енергозберігаючими технологіями при забезпеченні високої функціональності будівельних матеріалів на їх основі. У ряді робіт показано ефективність заміни частини клінкеру в складі цементів мінеральними добавками (цеоліт, шлак, зола винесу, високодисперсна крейда тощо), що наряду зі зменшенням емісії $\mathrm{CO}_{2}$ забезпечує підвищені експлуатаційні властивості бетонів і розчинів: міцність [1, 2], корозійну стійкість [3], водонепроникність [4], морозостійкість [5] тощо.

Найбільш перспективними в'яжучими речовинами, з огляду на сучасні тенденції сталого розвитку людства, $\epsilon$ шлаколужні цементи (далі ШЛЦ). Екологічний ефект використання ШЛЦ обумовлений можливістю утилізації побічних продуктів і відходів виробництва, збереженістю природних ресурсів і зменшенням емісії $\mathrm{CO}_{2}[6,7]$. При цьому бетони на основі ШЛЦ характеризуються більш високими показ-никами міцності [8], сульфатостійкості [9], морозостійкості [10] та атмосферостійкості $[11,12]$ порівняно 3 аналогами на основі традиційних клінкерних цементів як загальнобудівельного, так і спеціального призначення.

Довговічність ШЛЦ бетонів, у т. ч. армованих сталевою арматурою, отриманих iз жорстких бетонних сумішей на шлаколужних цементах, доведена багаторічним досвідом експлуатації [1315]. Однак сучасна практика будівництва висуває високі вимоги до технологічності бетонних сумішей. Виконання цих вимог викликає необхідність використовувати високорухомі бетонні суміші, що обумовлює зміни в структурі бетону, які можуть спричинювати порушення пасивного стану сталевої арматури. Вказане обумовлює необхідність розроблення заходів запобігання корозії сталевої арматури в ШЛЦ бетонах. Одним 3 таких засобів $є$ зменшення деформацій усадки, підвищення значення яких у ШЛЦ бетонах обумовлено високим вмістом гелевої фази в гідратованому ШЛЦ [16]. Високі значення усадки можуть призвести до підвищеного тріщиноутворення в бетоні і зменшення довговічності конструкцій у цілому.

Аналіз останніх досліджень i публікацій. Відомі засоби управління усадкою традиційних цементів $\epsilon$ неефективними у випадку лужних цементів $[17,18]$. Розглянуто принципову 
можливість зменшення деформації усадки ШЛЦ шляхом впливу на їх структуроутворення комплексними багатофункціональними добавками (далі КД) системи «портландцементний клінкер - сіль-електроліт - поверхнево-активна речовина (далі ПАР)» на основі сульфату натрію $\mathrm{Na}_{2} \mathrm{SO}_{4}$ і нітрату натрію $\mathrm{NaNO}_{3}[16$, 19, 20]. Перспективу як компонента КД має також сіль-електроліт у вигляді тринатрійфосфату $\mathrm{Na}_{3} \mathrm{PO}_{4}$ (далі ТНФ), що сповільнює строки тужавлення ШЛЦ [21, 22]. Крім того, ТНФ визначає зменшення капілярної пористості штучного каменю внаслідок ущільнення структури за рахунок формування гідроксіапатиту $\mathrm{Ca}_{10}\left(\mathrm{PO}_{4}\right)_{6}(\mathrm{OH})_{2}[23]$.

\section{Визначення мети та завдання} дослідження. Метою роботи $\epsilon$ обгрунтуван-ня складу КД системи «портландцементний клінкер - сільелектроліт - ПАР» для регулювання власних деформацій i міцності дрібнозернистого бетону на основі ШЛЦ (далі ШЛЦ бетону) із підвищенням щільності структури для попередження корозії сталевої арматури.

Для досягнення мети вирішувалися такі завдання:

- оптимізувати КД системи «портландцементний клінкер - сільелектроліт - ПАР» за критеріями власних деформацій і міцності ШЛЦ бетонів;

- обгрунтувати зазначені ефекти 3 точки зору впливу КД на структуроутворення ШЛЦ.

Сировинні матеріали. У дослідженнях як контрольний склад використано ШЛЦ такого складу: гранульований доменний шлак (далі ГДШ) - 88,20 \%, метасилікат натрію п'ятиводний $\left(\mathrm{Na}_{2} \mathrm{SiO}_{3} \cdot 5 \mathrm{H}_{2} \mathrm{O}\right)$ у сухому порошкоподібному стані - 11,80 \% (3,91\% в перерахунку на $\left.\mathrm{Na}_{2} \mathrm{O}\right)$.

ГДШ $\left(\mathrm{CaO}-44,60 \% ; \mathrm{SiO}_{2}-37,90 \%\right.$; $\mathrm{Al}_{2} \mathrm{O}_{3}-6,85 \% ; \mathrm{Fe}_{2} \mathrm{O}_{3}-0,31 \% ; \mathrm{MgO}-$ $5,21 \% ; \mathrm{Mn}-0,11 \% ; \mathrm{Na}_{2} \mathrm{O}+\mathrm{K}_{2} \mathrm{O}-1,13 \%$; $\left.\mathrm{TiO}_{2}-0,31 \%\right)$ характеризувався питомою поверхнею $4500 \mathrm{~cm}^{2} / \Gamma$ (за Блейном), модулем основності 1,11 і вмістом склофази $84,0 \%$.

Як складові КД використано:

- портландцементний клінкер (далі клінкер) $\left(\mathrm{CaO}-66,15 \% ; \mathrm{SiO}_{2}-22,61 \%\right.$; $\mathrm{Al}_{2} \mathrm{O}_{3}-5,29 \% ; \mathrm{Fe}_{2} \mathrm{O}_{3}-3,93 \% ; \mathrm{MgO}-$ $0,84 \% ; \mathrm{Na}_{2} \mathrm{O}-0,15 \% ; \mathrm{K}_{2} \mathrm{O}-0,98 \% ; \mathrm{SO}_{3}-$ $0,50 \%$ ) з питомою поверхнею $4500 \mathrm{~cm}^{2} / \Gamma$ (за Блейном);

- солі-електроліти - сульфат натрію $\mathrm{Na}_{2} \mathrm{SO}_{4}$ (CAS № 7757-82-6), нітрат натрію $\mathrm{NaNO}_{3}$ (CAS № 7631-99-4), ТНФ (CAS № 7601-54-9);

- ПАР двох типів - лігносульфонат натрію (далі ЛСТ) згідно з СAS № 8061-51$6(\mathrm{pH} \geq 8,5)$ і глюконат натрію (далі Гл) згідно з CAS № 527-07-1.

Як дрібний заповнювач ШЛЦ бетону використовували стандартний кварцовий пісок Гусарівського родовища (Україна) згідно з ДСТУ Б В.2.7-189:2009.

Методи досліджень. Водоредукуючий ефект дії КД оцінювали за зменшенням значень В/Ц дрібнозернистих бетонних сумішей (1:3) при розпливі на струшуючому столику 106-115 мм, виміряному згідно 3 ДСТУ Б В.2.7187:2009.

Міцність і власні деформації ШЛЦ бетону від технологічної вологості при висиханні до рівноважної визначали на зразках 40×40×160 мм. Після виготовлення зразки тужавіли у формах 3 ізольованою поверхнею впродовж однієї доби, після чого були розпалублені; сім діб зберігалися в нормальних умовах $\left(t=20 \pm 2{ }^{\circ} \mathrm{C}\right.$, R.H. $=95 \pm 5 \%)$ і після цього в ексикаторі над пересиченим розчином аміачної селітри $\left(\mathrm{NH}_{4} \mathrm{NO}_{3}\right)$ при температурі $t=20 \pm 2{ }^{\circ} \mathrm{C}$ та відносній вологості R.H.= $65 \%$ (стандартні умови згідно 3 національним стандартом України ДСТУ Б В.2.7-216). Такий режим зберігання зразків відповідає режимам тужавлення в реальних умовах на будівельному майданчику. При розрахунках власних деформацій ШЛЦ бетону вихідною прийнято довжину зразків на одну добу. 
Дослідження мікроструктури цементного каменю після 28 діб тужавлення в нормальних умовах здійснено за допомогою зондового аналізу на растровому електронному мікроскопімікроаналізаторі.

Оптимізацію складів КД здійснювали за допомогою методів математичного планування експерименту; розрахунки здійснювали в програмному середовищі Statistica. Як вихідні критерії оцінювання при оптимізації складів КД прийнято усадку ШЛЦ бетону при задовільних значеннях міцності на згин і стиск на 2 і 28 добу тужав-лення (не менше контрольного складу).

Основна частина дослідження. Дрібнозернистий бетон на основі ШЛЦ системи «ГДШ - метасилікат натрію» (контрольний склад) при $\mathrm{B} / Ц=0,29$ характеризується такими показниками після тужавлення: міцність на згин / стиск (МПа) на 2 добу - 5,0 / 28,8, на 28 добу 7,5 / 50,3. Усадка контрольного складу на 104 добу становить 0,984 мм/м.

Оптимізацію складів КД системи «клінкер - сіль-електроліт - ПАР» здійснено за двофакторним трирівневим планом експерименту. Як змінні фактори прийнято: $\mathrm{X}_{1}$ - вміст клінкеру в складі КД, 4,00-10,00\% маси ГДШ; $\mathrm{X}_{2}$ - вміст соліелектроліту $\left(\mathrm{Na}_{3} \mathrm{PO}_{4}, \mathrm{Na}_{2} \mathrm{SO}_{4}\right.$ i $\left.\mathrm{NaNO}_{3}\right)$ в складі КД, 1,50-2,50 \% маси ГДШ. Вміст ПАР в складі КД прийнято у відсотках маси ГДШ: ЛСТ - 0,30, Гл - 0,15. Наведені інтервали зміни факторів обумовлені передбаченими областями можливої зміни усадки ШЛЦ бетону згідно з результатами попередніх досліджень [16, 19, 20].

Побудовано криві зміни усереднених значень усадки ШЛЦ бетону, модифікованого КД оптимізованих складів на основі $\mathrm{NaNO}_{3}, \mathrm{Na}_{2} \mathrm{SO}_{4}$ і $\mathrm{Na}_{3} \mathrm{PO}_{4}$ (рис. 1). Використання КД забезпечує зменшення В/Ц 3 0,29 (для контрольного складу) до 0,26.

Визначено оптимальний склад КД на основі $\mathrm{NaNO}_{3}, \%$ маси ГДШ: ЛСТ - 0,30, Гл - 0,15, клінкер - 6,50-7,70, $\mathrm{NaNO}_{3}-$ 1,40-2,00. $\mathrm{y}$ даному випадку спостерігається збільшення міцності затужавілого ШЛЦ бетону на згин / стиск 3 5,0 / 28,8 МПа до $(6,0-6,3)$ / $(26,0-28,0)$ МПа на 2 добу, $3 \quad$ 7,5 / 50,3 МПа до (8,8$9,4)$ / $(48,0-50,0)$ МПа на 28 добу. При цьому усадка ШЛЦ бетону впродовж 48 діб збільшується до $0,750 \mathrm{mм} / \mathrm{M}$, після чого спостерігається тенденція до розширення і на 104 добу усадка зменшується 3 0,984 (контрольний склад) до 0,560-0,605 мм/м (рис. 1).

Оптимізований склад КД на основі $\mathrm{Na}_{2} \mathrm{SO}_{4}, \%$ маси ГДЩ: ЛСТ - 0,30, Гл 0,15 , клінкер - 4,00-4,65, $\mathrm{Na}_{2} \mathrm{SO}_{4}-1,50$ 1,59. При використанні КД в цьому випадку спосте-рігається збільшення міцності затужавілого ШЛЦ бетону: міцність на згин / стиск - $(8,5-8,8)$ / $(32,0-34,0)$ МПа на 2 добу і $(12,0-12,7)$ / $(54,0-56,0)$ МПа на 28 добу. Після збільшення усадки до 0,8300,814 мм/м на 55 добу спостерігається компенсація власних деформацій, що супроводжується зменшенням усадки до 0,625-0,640 мм/м на 104 добу (рис. 1). 


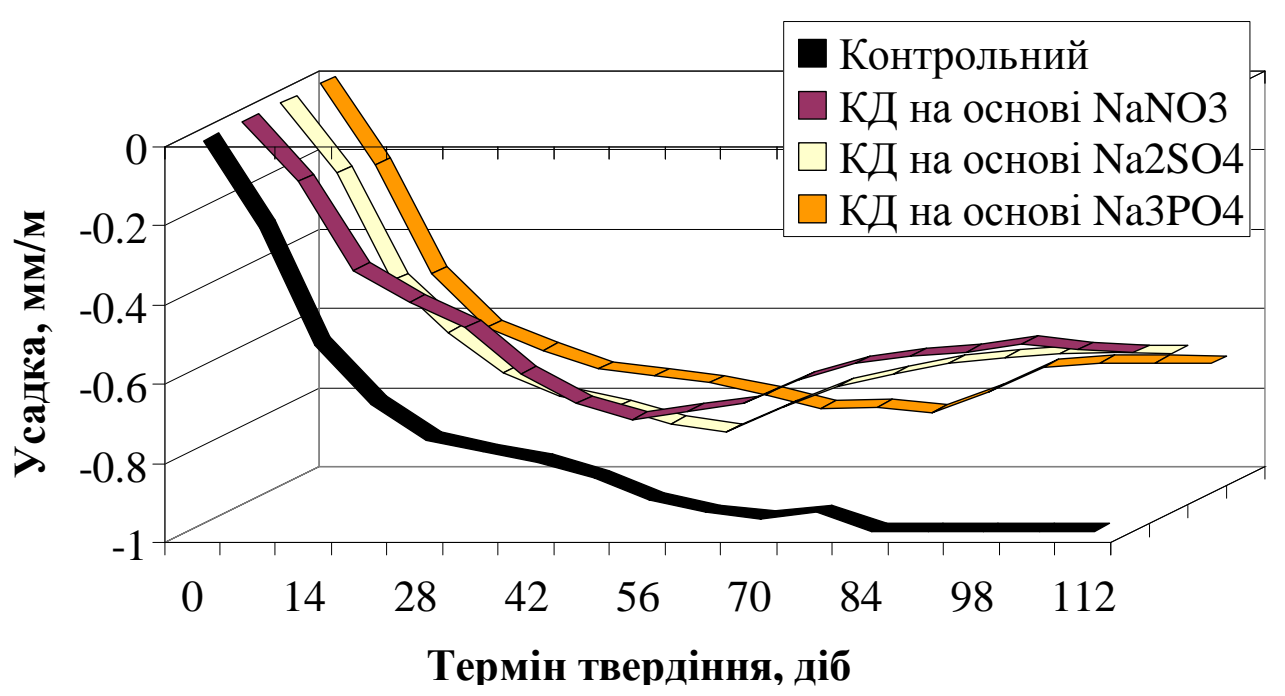

Рис. 1. Криві зміни середніх значень усадки ШЛЦ бетонів

Виявлено також оптимальний склад КД на основі $\mathrm{Na}_{3} \mathrm{PO}_{4}, \%$ маси ГДЩ: ЛСТ 0,30, Гл - 0,15, клінкер - 4,00-4,60, $\mathrm{Na}_{2} \mathrm{SO}_{4}$ - 1,80-2,05. Міцність на згин / стиск ШЛЦ бетону, модифікованого такою КД, збільшується внаслідок зменшення В/Ц до $(6,1-6,5)$ / $(27,0-29,0)$ МПа на 2 добу і до $(9,5-10,0)$ / $(49,0-51,0)$ МПа на 28 добу. Має місце певне розширення ШЛЦ бетону після 76 доби, внаслідок чого усадка зменшується до $0,713-0,700 \mathrm{mм} / \mathrm{M}$ на 104 добу (рис. 1).

У загальному випадку зменшення усадки обумовлено як водоредукуючим ефектом дії КД, так і впливом КД на процеси структуроутворення штучного каменю, що пояснюе різну міцність. Особливості фор-мування мікроструктури ШЛЦ, модифікова-них КД, вивчено за допомогою електронної мікроскопії i зондового аналізу (рис. 2).

Аналіз електронних фотографій мікроструктури гідратованого ШЛЦ дозволяе ідентифікувати низькоосновні гідросилікати кальцію в субмікрокристалічному (гелеподібному) стані (рис. 2, а), що й обумовлює підвищені значення усадки ШЛЦ бетону (вміст оксидів, за зондовим аналізом, \%: $\mathrm{CaO}-32,16, \mathrm{SiO}_{2}-37,82$, $\mathrm{Al}_{2} \mathrm{O}_{3}-12,48, \mathrm{Na}_{2} \mathrm{O}-9,77, \mathrm{MgO}-5,03, \mathrm{SO}_{3}$ $-2,73)$.
Порівняно з результатами попередніх досліджень [16, 20] зафіксовано підвищення ступеня кристалічності гідратних фаз ШЛЦ при використанні КД оптимізованого складу. За результатами електронної мікроскопії, використання КД на основі $\mathrm{NaNO}_{3}$ сприяе утворенню шаруватих пластинчастих кристалічних формувань, які можна віднести до гідронітроалюмінату кальцію $3 \mathrm{CaO} \cdot \mathrm{Al}_{2} \mathrm{O}_{3} \cdot \mathrm{Ca}\left(\mathrm{NO}_{3}\right)_{2} \cdot 10 \mathrm{H}_{2} \mathrm{O}$ відповідно до вмісту оксидів, за зондовим аналізом, \%: $\mathrm{CaO}-38,26, \mathrm{Al}_{2} \mathrm{O}_{3}-17,87, \mathrm{~N}_{2} \mathrm{O}-21,87$, $\mathrm{MgO}-2,47, \mathrm{SO}_{3}-1,40$ ) (рис. 2, б) [24].

у фазовому складі ШЛЦ, модифікованого КД на основі $\mathrm{Na}_{2} \mathrm{SO}_{4}$, спостерігаються гексагональні пластинчасті кристалічні структури типу мінаміiту $\left(\mathrm{Na}, \mathrm{Ca}_{0.5}\right) \mathrm{Al}_{3}\left(\mathrm{SO}_{4}\right)_{2}(\mathrm{OH})_{6}$ (вміст оксидів, за зондовим аналізом, \%: $\mathrm{CaO}-$ 4,51, $\mathrm{Al}_{2} \mathrm{O}_{3}-37,77, \mathrm{SO}_{3}-36,41, \mathrm{Na}_{2} \mathrm{O}-$ 3,80 ) (рис. 2, в) [25]. Крім того, у складі продуктів гідратації ШЛЦ, модифікованого КД на основі $\mathrm{Na}_{3} \mathrm{PO}_{4}$ разом 3 гідросилікатами і гідроалюмосилі-катами кальцію формуються тонкопластин-часті пірамідальні кристали гідроксіапатиту кальцію $\mathrm{Ca}_{10}\left(\mathrm{PO}_{4}\right)_{6}(\mathrm{OH})_{2}$ (вміст оксидів, за зондовим аналізом, \%: $\mathrm{CaO}-57,82, \mathrm{Al}_{2} \mathrm{O}_{3}-$ $5,34, \mathrm{P}_{2} \mathrm{O}_{5}-47,82, \mathrm{Na}_{2} \mathrm{O}-0,64$ ) (рис. 2, г) [23]. 
a)

в)
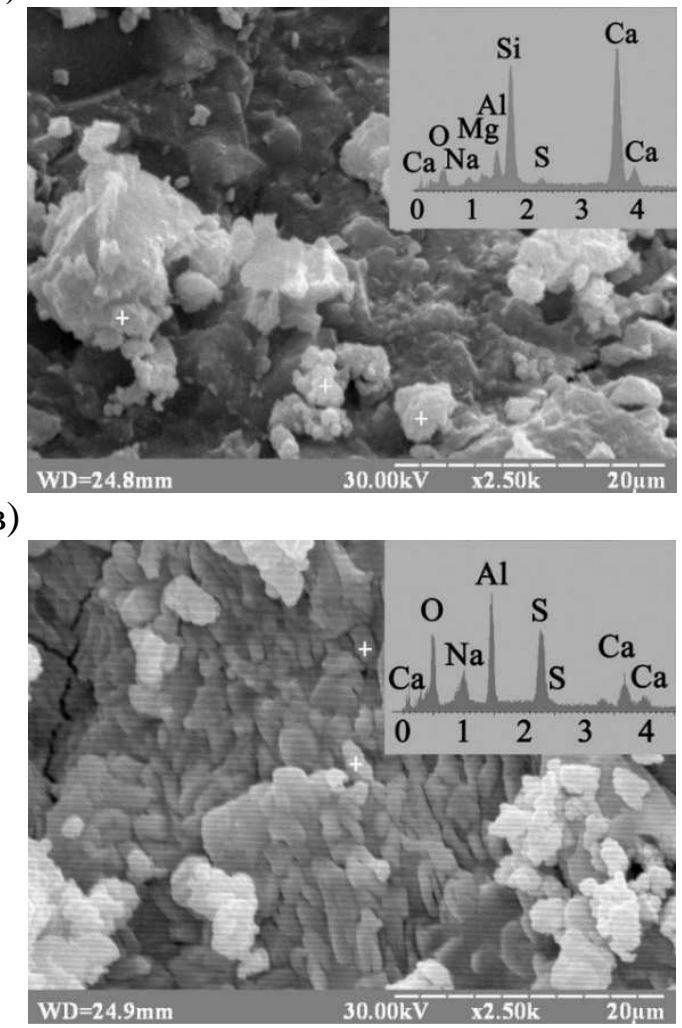

б)

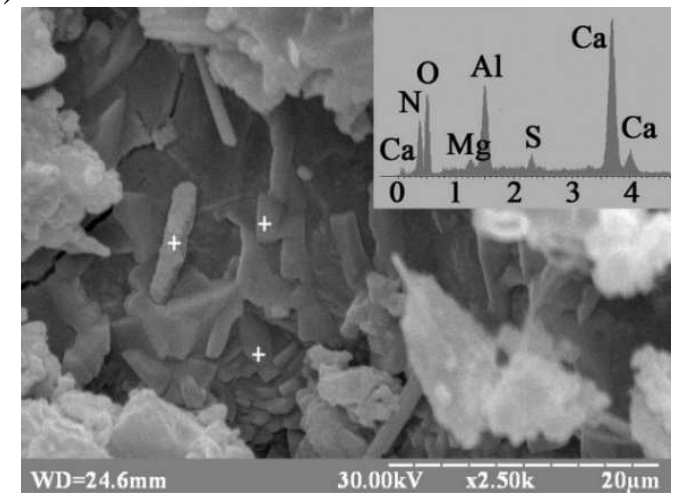

г)

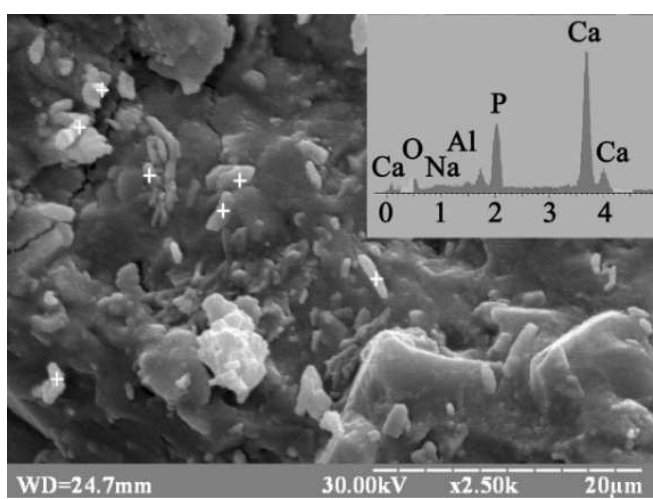

Рис. 2. Електронні мікрофотографії поверхні сколу ШЛЦ після 28 діб тужавлення: контрольний (немодифікований) (а); модифікований КД на основі $\mathrm{NaNO}_{3}$ (б); модифікований КД на основі $\mathrm{Na}_{2} \mathrm{SO}_{4}$ (в); модифікований КД на основі $\mathrm{Na}_{3} \mathrm{PO}_{4}($ г)

\section{Висновки:}

1. Оптимізація складу КД системи «клінкер - сіль-електроліт - ПАР» на основі $\mathrm{NaNO}_{3}, \mathrm{Na}_{2} \mathrm{SO}_{4}$ i $\mathrm{Na}_{3} \mathrm{PO}_{4}$ дозволила зменшити усадку ШЛЦ бетону на 104 добу тужавлення $з$ 0,984 до 0,560-0,605 мм/м, $0,625-0,640 \mathrm{Mm} / \mathrm{M}$ i $\quad 0,713-0,700 \mathrm{MM} / \mathrm{M}$ відповідно. При цьому міцність ШЛЦ бетону, модифікованого КД, практично відповідає значенням контрольного складу.

2. Регулювання власних деформацій модифікованого ШЛЦ бетону в напрямку зменшення усадки при збереженні міцності забезпечується зменшенням вмісту води, створенням додаткового напруження в міжфазному просторі гідратних новоутворень ШЛЦ завдяки прискореному формуванню кристалів мінамііту, гідронітроалюмінату кальцію і гідроксіапатиту відповідно до аніонної складової, використаної в

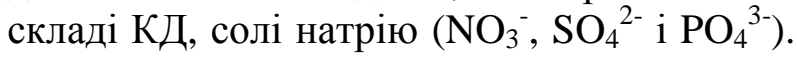
Зменшення деформацій усадки при підвищенні щільності порової структури штучного каменю знижує схильність до тріщиноутворення і відповідно зменшує ризик ініціації корозії сталевої арматури.

Подяка. Автори висловлюють подяку за фінансову підтримку роботи, що виконується в рамках бюджетного фінансування № 1020U001010, а також за розвиток теми досліджень за програмою наукового співробітництва COST Action CA15202 SARCOS «Self-Healing concrete: the path to sustainable construction», що діє в рамках проекту європейського рівня HORIZON 2020, http://www.cost.eu/COST_Actions/ca/CA15202.

Список використаних джерел 
1. Kropyvnytska T., Rucinska T., Ivashchyshyn H., Kotiv R. Development of Eco-Efficient Composite Cements with High Early Strength. International Lecture Notes in Civil Engineering. 2020. Vol. 47. P. 211-218. DOI: https://doi.org/10.1007/978-3-030-27011-7_27.

2. Markiv T., Sobol K., Petrovska N., Hunyak O. The Effect of Porous Pozzolanic Polydisperse Mineral Components on Properties of Concrete. Lecture Notes in Civil Engineering. 2020. Vol. 47 P. 275-282. DOI: https://doi.org/10.1007/978-3-030-27011-7_35.

3. Borziak O. S., Plugin A. A., Chepurna S. M., Zavalniy O. V., Dudin O. A. The effect of added finely dispersed calcite on the corrosion resistance of cement compositions. IOP Conference Series. Materials Science and Engineering. 2019. Vol.708(1). 012080. DOI: https://doi.org/10.1088/1757-899X/708/1/012080.

4. Borziak O., Chepurna S., Zidkova T., Zhyhlo A., Ismagilov A. Use of a highly dispersed chalk additive for the production of concrete for transport structures. MATEC Web of Conferences. 2018. Vol. 230. 03003. DOI: https://doi.org/doi.org/10.1051/matecconf/201823003003.

5. Moskalenko O., Runova R. Ice Formation as an Indicator of Frost-Resistance on the Concrete Containing Slag Cement in Conditions of Freezing and Thawing. Materials Science Forum. 2016. Vol. 865. P. 145-150. DOI: https://doi.org/10.4028/www.scientific.net/MSF.865.145.

6. Provis J. L., van Deventer J. S. J. Geopolymers and Other Alkali-Activated Materials. In book: Lea's Chemistry of Cement and Concrete, Elsevier. 2019. P. 779-805. DOI: https://doi.org/ 10.1016/B978-0-08-100773-0.00016-2.

7. Krivenko P., Petropavlovskyi O., Kovalchuk O., Lapovska S., Pasko A. Design of the composition of alkali activated portland cement using mineral additives of technogenic origin. Eastern-European Journal of Enterprise Technologies. 2018. Vol. 4(6-94). P. 6-15. DOI: https://doi.org/ 10.15587/1729-4061.2018.140324.

8. Chistyakov V. V., Grankovskii I. G., Gots V.I. Structure formation upon hardening of slagalkali binder. Journal of applied chemistry of the USSR. 1986. 59, 3 pt 1. P. 542-546.

9. Kryvenko P., Guzii S., Kovalchuk O., Kyrychok V. Sulfate resistance of alkali activated cements. Materials Science Forum. 2016. Vol.865. P.95-106. DOI: https://doi.org/10.4028/www.scientific.net/MSF.865.95.

10. Krivenko P., Petropavlovskyi O., Kovalchuk O. A comparative study on the influence of metakaolin and kaolin additives on properties and structure of the alkali-activated slag cement and concrete. Eastern-European Journal of Enterprise Technologies. 2018. Vol. 1, № 6 (91). P. 33-39. DOI: https://doi.org/10.15587/1729-4061.2018.119624.

11. Pushkarova E., Gots V., Gonchar O. Stability of hydrosulfoaluminosiljcate compounds and durability of an artificial stone based on them. Brittle Matrix Composites. Vol. 8. 2006. P. 399408.

12. Pushkarova E., Gots V., Gonchar O. Stability of hydrosulfoaluminosiljcate compounds and durability of an artificial stone based on them (Book Chapter). Brittle Matrix Composites. 2007. Vol. 8. P. 399-408. DOI: https://doi.org/10.1533/9780857093080.399.

13. Рунова Р. Ф., Носовський Ю. Л., Дворкін Л. Й., Дворкін О. Л. В’яжучі речовини: підручник. Київ: Основа, 2012. 448 с.

14. Bernal S. A., Provis J. L. Durability of alkali-activated materials: Progress and perspectives. Journal of the American Ceramic Society. 2014. Vol. 97 (4). P. 997-1008.

15. Awoyera P., Adesina A. Durability Properties of Alkali Activated Slag Composites: Short Overview. A. Silicon. 2020. 12. P. 987-996. DOI: https://doi.org/10.1007/s12633-019-001991 .

16. Krivenko P., Gots V., Petropavlovskyi O., Rudenko I., Konstantynovskyi O., Kovalchuk A. Development of decisions for alkali-activated cements proper deformations control. Eastern- 
European journal of Enterprise Technologies. 2019. Vol. 5, № 6 (101). P. 24-32. DOI: https://doi.org/10.15587/1729-4061.2019.181150.

17. Yuan X.-H., Chen W., Lu Z.-A., Chen H. Shrinkage compensation of alkali-activated slag concrete and microstructural analysis. Construction and Building Materials. 2014. Vol. 66422428. DOI: https://doi.org/10.1016/j.conbuildmat.2014.05.085.

18. Штарк Й., Вихт Б. Цемент и известь: монография / пер. с нем. А.Тулаганова; под ред. П. Кривенко. Киев, 2008. 480 с.

19. Krivenko P., Petropavlovskyi O., Rudenko I., Konstantynovskyi O., Kovalchuk A. Alkali activated portland cement with adjustable proper deformations for anchoring application. IOP Conference Series: Materials Science and Engineering (MSE). 2019. Vol. 708. 012090. DOI: https://doi.org/10.1088/1757-899X/708/1/012090.

20. Krivenko P., Petropavlovskyi O., Rudenko I., Konstantynovskyi O. The influence of complex additive on strength and proper deformations of alkali-activated slag cements. Materials Science Forum. 2019. Vol.968. P. 13-19. DOI: https://doi.org/10.4028/www.scientific.net/ MSF.968.13.

21. Kalina L., Bílek V., Komosná K., Novotný R., Tkacz J. Effect of Phosphates on the Hydration Process of Alkali Activated Materials. Materials Science Forum. 2016. Vol. 851. P. 6368. DOI: 10.4028/www.scientific.net/MSF.851.63.

22. Krivenko P., Petropavlovskyi O., Kovalchuk O., Rudenko I., Konstantynovskyi O. Enhancement of alkali-activated slag cement concretes crack resistance for mitigation of steel reinforcement corrosion. E3S Web of Conferences. 2020. Vol. 166. 06001. DOI: https://doi.org/10.1051/e3sconf/202016606001.

23. Kalina L., Bílek V., Novotný R., Mončeková M., Másilko J., Koplík J. Effect of $\mathrm{Na}_{3} \mathrm{PO}_{4}$ on the Hydration Process of Alkali-Activated Blast Furnace Slag. Materials. 2016. Vol. 9(5). № 395. DOI: https://doi.org/10.3390/ma9050395.

24. Plugin A. A., Runova R. F. Bonding calcium chloride and calcium nitrate into stable hydration portland cement products. Stability conditions of calcium hydrochloraluminates and calcium hydronitroaluminates. International Journal of Engineering Research in Africa. 2018. Vol. 36. P. 69-73. DOI: https://doi.org/10.4028/www.scientific.net/JERA.36.69.

25. Bayliss P., Kolitsch U, Nickel E., Pring A. Alunite supergroup: recommended nomenclature. Mineralogical Magazine. 2016. Vol. 74 (5). P.919-927. DOI: https://doi.org/10.1180/ minmag.2010.074.5.919.

Кривенко Павло Васильович, доктор технічних наук, професор, директор Науково-дослідного інституту в’яжучих речовин і матеріалів Київського національного університету будівництва і архітектури. ORCID iD: 0000-0001-7697-2437. Тел.: (044) 245-48-30. E-mail: pavlo.kryvenko@ gmail.com.

Петропавловський Олег Миколайович, кандидат технічних наук, старший науковий співробітник Науководослідного інституту в'яжучих речовин і матеріалів Київського національного університету будівництва і архітектури. ORCID iD: 0000-0002-3381-1411. Тел.: (044) 241-54-44. E-mail: oleg.petropavlovskii @ gmail.com. Руденко Ігор Ігоревич, кандидат технічних наук, старший науковий співробітник Науково-дослідного інституту в'яжучих речовин і матеріалів Київського національного університету будівництва і архітектури. ORCID iD: 0000-0001-5716-8259. Тел.: (044) 241-54-92. E-mail: igor.i.rudenko@gmail.com.

Константиновський Олександр Петрович, кандидат технічних наук, доцент кафедри технології будівельних конструкцій і виробів Київського національного університету будівництва і архітектури. ORCID iD: 0000-0002-7936-5699. Тел.: (044) 245-48-43. E-mail: alexandrkp@ gmail.com.

Kryvenko Pavlo Vasylovych, DSc (Eng), Prof., Director, Scientific Research Institute for Binders and Materials, Kyiv national university of construction and architecture. ORCID iD: 0000-0001-7697-2437. Tel.: (044) 245-48-30. E-mail: pavlo.kryvenko@gmail.com.

Petropavlovskyi Oleh Mykolaiovych, PhD (Eng), Chief scientist, Scientific Research Institute for Binders and Materials, Kyiv national university of construction and architecture. ORCID iD: 0000-0002-3381-1411. 
Tel.: (044) 241-54-44. E-mail: oleg.petropavlovskii@gmail.com.

Rudenko Igor Igorevych, $\mathrm{PhD}$ (Eng), Senior scientist, Scientific Research Institute for Binders and Materials, Kyiv national university of construction and architecture. ORCID iD: 0000-0001-5716-8259. Tel.: (044) 241-54-92.

E-mail: igor.i.rudenko@gmail.com.

Konstantynovskyi Oleksandr Petrovych, PhD (Eng), Associate Professor, technology of building constrictions and products (TBCP) department, Kyiv National University of Construction and Architecture. ORCID iD: 0000-0002-79365699. Tel.: (044) 245-48-43. E-mail: alexandrkp@gmail.com.

Статтю прийнято 18.12 .2019 р. 